\title{
Ernsts fon Bergmanis un Latvija
}

Pārskats veidots, balstoties referātā, kas nolasīts Ernsta fon Bergmaņa 175 gadu jubilejas sarīkojumā Paula Stradiņa Medicīnas vēstures muzejā 2011. gada 7. decembrī un agrāk publicētā rakstā ar līdzīgu nosaukumu. ${ }^{1}$ Dati smelti no labi zināmiem avotiem: Ārenda Buholca monogrāfijas par Ernstu fon Bergmani² un viņa jaunākā brāļa Eduarda fon Bergmaņa pētījuma par dzimtas izcelsmi un gaitu, ${ }^{3}$ kā arī no apraksta par mācītāju Bergmaņu darba simtgadi Rūjienā. ${ }^{4}$ Tie savukārt dažviet papildināti ar arhīva atradumiem, publikācijām periodikā u. c.

Ernsts fon Bergmanis ir viens no izcilākajiem pasaules ķirurgiem, Tērbatas universitātes audzēknis, tajā arī 1860. gadā aizstāvējis doktora disertāciju, bijis asistents, docents, no 1871. gada - profesors, vēlāk akadēmisko karjeru turpinājis no 1878. gada Vircburgā un no 1882. gada Berlīnē, sasniedzot savam laikam iespējami augstāko akadēmisko stāvokli un pa vidu piedaloties vairākos karos. 1890. gadā Ernsts fon Bergmanis definēja aseptikas pamatlikumu, proti, visam, kas saskaras ar brūci, jābūt sterilam. Aseptika tika vērsta pret mikroorganismu iekļūšanu brūcē, audos, orgānos un ķermeņa dobumos operāciju u. c. manipulāciju gaitā.

1 Vīksna A. Ernsts fon Bergmanis Latvijā // Latvijas Ārsts, 1992; 6: 643.-646. lpp.

2 Buchholtz A. Ernst von Bergmann. Mit Bergmanns Kriegsbriefen von 1866, 1870/71 und 1877. - Leipzig, 1911. - 646 S.

3 Bergmann E. Des Palm Bergmann Nachkommen 1672-1886. - R., 1886. - 95 S.

${ }^{4}$ Bergmann E. Das Säcularfest der Familie Bergmann in der Pfarre Rujen. Berlin, 1885. $-55 \mathrm{~S}$. 
To panāca ar instrumentu, operācijas materiālu un aparātu sterilizāciju, ķirurga roku īpašu apstrādi pirms operācijas, īpašu paņēmienu lietošanu operācijas gaitā un telpā u. tml. Citi E. fon Bergmaņa pētījumi bija neiroķirurǵijā, karalauka ķirurǵijāa, abdominālajā ķirurǵijā, onkoloǵijā, kā arī par lepru Vidzemē.

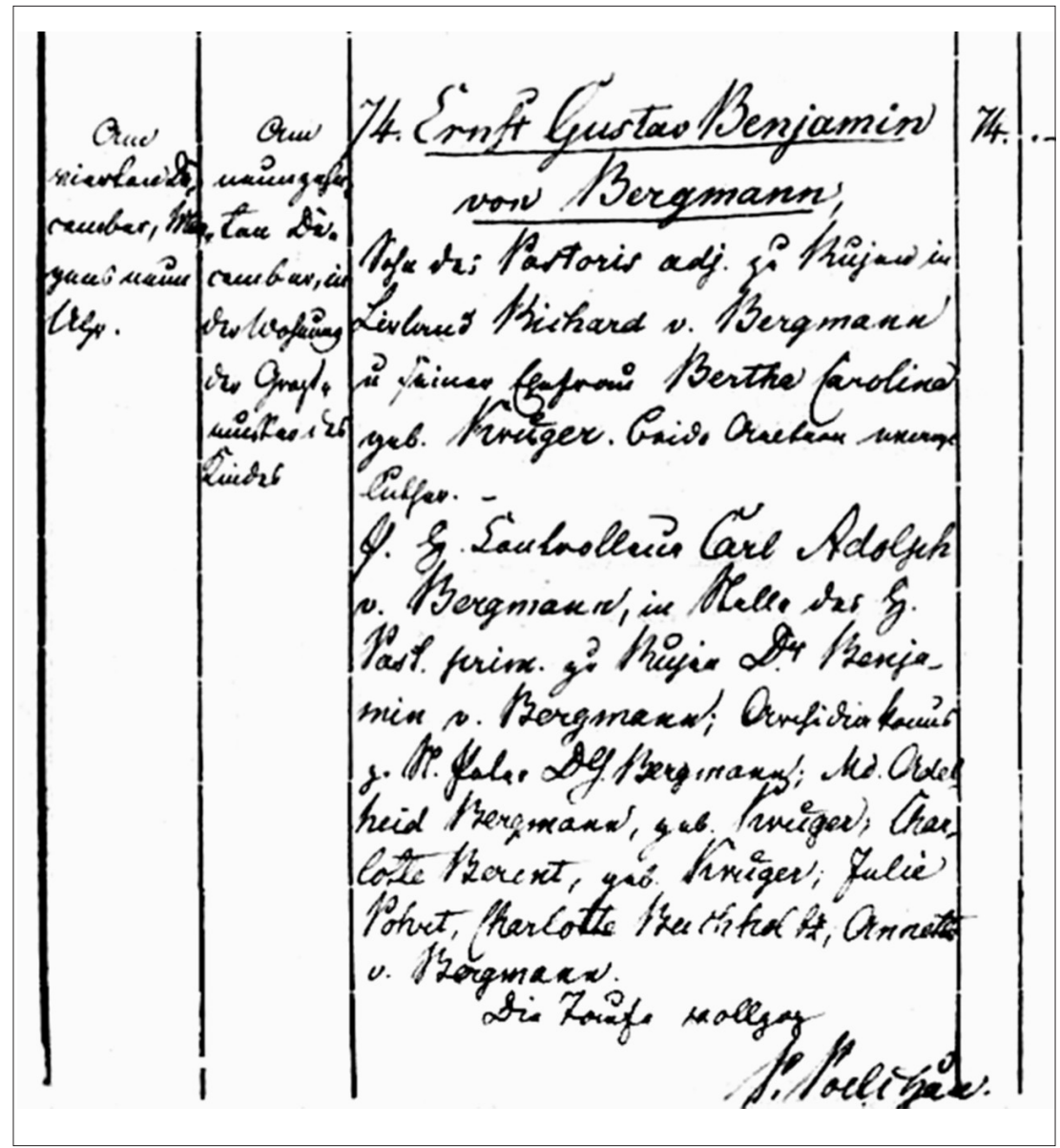

1836. gada ieraksts Rīgas Doma draudzes metriku grāmatā par Ernsta fon Bergmaña kristīšanu ${ }^{5}$

${ }^{5}$ LVVA, 1426. f., 2. apr., 31. 1., 86. 1p. 


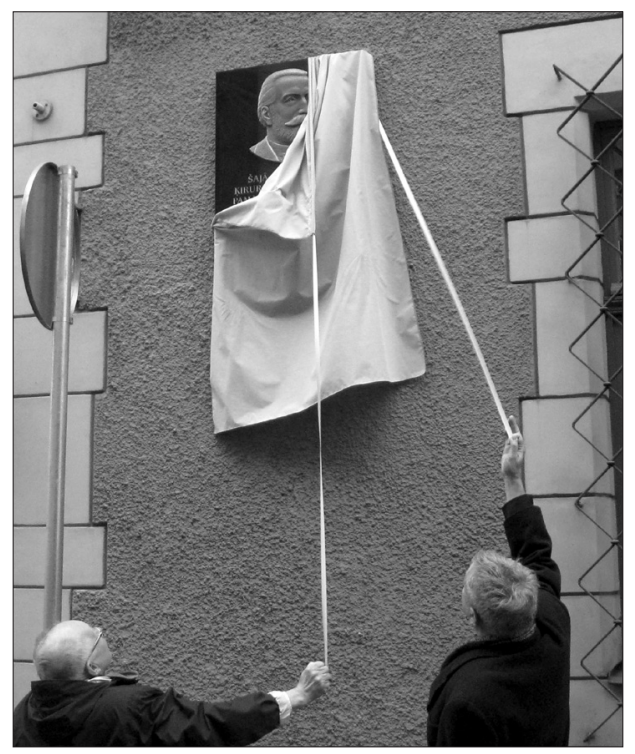

Ernsta fon Bergmaņa piemiņas plāksnes atklāšana 2011. gada 16. decembrī Rīgā pie nama Pils ielā 11

Ernsts fon Bergmanis dzimis 1836. gada 4. (16.) decembrī Rīgā, bet norādi par konkrētu vietu sniedzis jau minētais $\bar{A}$. Buholcs - tas noticis Pils ielā 11. ${ }^{6}$ Tā kā Rīgā ir divas Pils ielas - Lielā un Mazā, - salīdzinājumam tika izmantotas 19. gs. un 20. gs. sākuma Rīgas adrešu grāmatas. M. Pils ielā 11 mājojusi grieķu katoḷu (proti, pareizticīgo) sinode, bet nama L. Pils ielā 11 vietā pēc arhitekta Vilhelma Bokslafa projekta 1901. gadā uzcelts anglı jūrnieku klubs, ${ }^{7}$ kas tagad nodots Dānijas Karalistes vēstniecībai. Pie šā nama fasādes piestiprināta un 2011. gada 16. decembrī atklāta piemiñas plāksne Ernstam fon Bergmanim ar tekstu latviešu un vācu valodā un portretu, ko darinājis tēlnieks Jānis Strupulis.

Ernsta Gustava Benjamina fon Bergmaņa dzimšana reǵistrēta Rīgas Doma draudzes metrikā 1836. gada 20. decembrī, kristības notikušas viṇa mātes vecāku dz̄ivoklī jau minētajā namā, piedaloties vecākiem -

6 Buchholtz A. Ernst von Bergmann. S. 54, 55.

7 Krastiņš J., Strautmanis I. Lielais Rīgas arhitektūras cel̦vedis. - Rīga, b. g. -63 . lpp. 
palīgmācītājam Rihardam fon Bergmanim (1805-1878) un viṇa dzīvesbiedrei Bertai Karolinai, dzim. Krīgerei (1816-1877), kā arī citiem tuviniekiem Doma mācītāja, vēlāk bīskapa Pētera Pelhaua (1803-1874) vadībā. ${ }^{8}$ Ernsts ir mātes tēva, Gustavs un Benjamins - vecvectēva un vectēva vārds no tēva puses.

Ernsta fon Bergmaņa bērnība un jaunība ir saistīta ar Rūjienu, kas bijusi vairāku viṇa priekšteču dzīves un darbavieta. Bergmaņu dzimta, kā tas plaši aprakstīts jau minētajā ǵenealoǵiskā literatūrā un paša Ernsta saviem senčiem veltītā pētījumā, ${ }^{9}$ bijusi pazīstama no 16. gs., varbūt pat no 13. gs. Austrumprūsijā. Kāds no viniiem, Ambrozijs Bergmanis (1641-1677), kas šajā gadījumā veido nosacītu 1. paaudzi, pēc studijām no Karal̦aučiem ieklīdis Vidzemē, bijis mājskolotājs, īsu laiku - no 1667. līdz 1668. gadam - palīgmācītājs Rūjienā, vēlāk Igaunijā. Viņa pēcteči ar laiku labi iejutušies Baltijā un Krievijā, bet profesionāli vairāk pievērsušies teoloǵijai un medicīnai.

Bergmaņu 2. paaudzi pārstāv Palms (1672-1751), turīgs Rīgas tirgotājs, kam ir vairāki simti tiešo pēcteču līdz pat mūsu dienām. Palma dēls Baltazars (1703-1768), no 3. paaudzes, bijis mācītājs Ādažos ar četriem dēliem, kas jau ietilpst 4. paaudzē:

1) Baltazaru (1736-1789) - juristu Rīgā;

2) Ambroziju (1740-1784) - ārstu Rīgā un Krievijas armijā; interesi izraisa viņa 1762. gadā Leipcigā aizstāvētā doktora disertācija par Livonijas iedzīvotāju veselības stāvokli "De ruricolarum Livoniae statu sano et morboso", kas ir nozīmīgs Latvijas medicīnas vēstures avots;

3) Gustavu - Rūjienas mācītāju Bergmaņu dinastijas aizsācēju;

4) Liboriju (1754-1823) - literātu un Rīgas Doma un Pētera baznīcas mācītāju.

Gustavs (1749-1814), kas 1787. gadā inskribēts Vidzemes bruṇniecībā ar sev un pēctečiem mantojamu titulu "fon", ko pats gan nelietoja, aiz Ernsta fon Bergmaņa ir otrs izcilākais šās dzimtas pārstāvis. Studējis teoloǵiju Leipcigā un duelējies ar studiju biedru Johanu Volfgangu fon Gēti, kuru ievainojis; bijis mācītājs Āraišos un Mazsalacā, no 1785. gada līdz mūža

8 LVVA, 1426. f., 2. apr., 31 1., 86. 1p.

9 Bergmann E. Von unseren Vorfahren: eine Familienchronik. Th. 1. - Berlin, 1896. - $246 \mathrm{~S}$. 
beigām - Rūjienā, iedibinot Rūjienas mācītāju Bergmaņu dinastiju. Gustavs daudz veicis dažādās nozarēs, vispirms jau novada un Baltijas iedzīvotāju garīgā aprūpē. Savukārt iedzīvotāju veselības aprūpē, piemēram, neizmērojami lieli ir viņa nopelni baku potēšanā (ar variolācijas metodi), ko pats savām rokām viņš veicis 12 tūkstošiem bērnu (miruši pieci), par ko 1802. gadā no imperatora Aleksandra I saņēmis zelta medaļu. Gustavs daudz pūlējies kultūras jomā - savācis un savā tipogrāfijā Rūjienā nodrukājis divus latviešu tautasdziesmu krājumus, veicis vēsturiskus un etnogrāfiskus pētījumus, izdevis Vidzemes kalendārus, sprediķu grāmatas un citus - kopā 200 - darbus, sagatavojis latviešu-vācu un vācu-latviešu vārdnīcu. Šķiet dīvaini, ka šis liela gara cilvēks tomēr 1806. gadā bijis iniciators pēdējai raganas prāvai Vidzemē (nelaimīgā Mārieta gan netika sadedzināta). Par viņa dzīvi iedvesmojošu grāmatu emigrācijā publicējis vēsturnieks Arveds Švābe. ${ }^{10}$

No Gustava dēliem, kas pārstāv 5. paaudzi, jānosauc Benjamins, Ambrozijs un Kārlis. Benjamins (1792-1846) pēc studijām Leipcigā un Jēnā bija mājskolotājs pie Gončaroviem Maskavā (Natālija Gončarova kḷuva par Aleksandra Puškina dzīvesbiedri), pētīja kalmiku valodu un etnogrāfiju, vēlāk - sanskritu un izveidojās par profesionāla līmeņa valodnieku; pēc tam bija mācītājs Ērgḷos un pēc tēva vēlmes - no 1814. gada Rūjienā. Viṇa brālis medicīnas doktors Ambrozijs (1774-1814) kalpoja kņazam Nariškinam un grāfam Stroganovam Krievijā. Jaunākāa brāḷa Kārḷa (1783-1844) līnija īpašu vērību gūst tālab, ka viņa dēls Ādolfs (1824-1911) bija ārsts Petrozavodskā, bet mazdēls, arī Ādolfs (1855-1922), - l̦oti krietns Rīgas ķirurgs, par kuru - nedaudz vēlāk. Šis Ādolfs, kas literatūrā reizēm neprecīzi saukts par Ernsta brālēnu, patiesībā ir otrās pakāpes brālēns, jo abiem kopīgs bijis nevis vectēvs, bet gan vecvectēvs Gustavs.

Tālāk ejot, 6. paaudzi šais radurakstos pārstāv Benjamina dēls Rihards fon Bergmanis, kas ir Ernsta tēvs un trešais pēc kārtas mācītājs Bergmanis Rūjienā no 1842. gada. Viņš krietni pūlējies izglītības un kultūras laukā, piemēram, līdzējis Jurim Neikenam sasaukt pirmos latviešu Dziesmu svētkus Dikḷos 1864. gadā, tomēr aiz citiem Bergmaņiem mazāk nomanāms.

10 Švābe A. Kāda mācītāja dzīve. - Stokholma, 1958. - 216 lpp. 


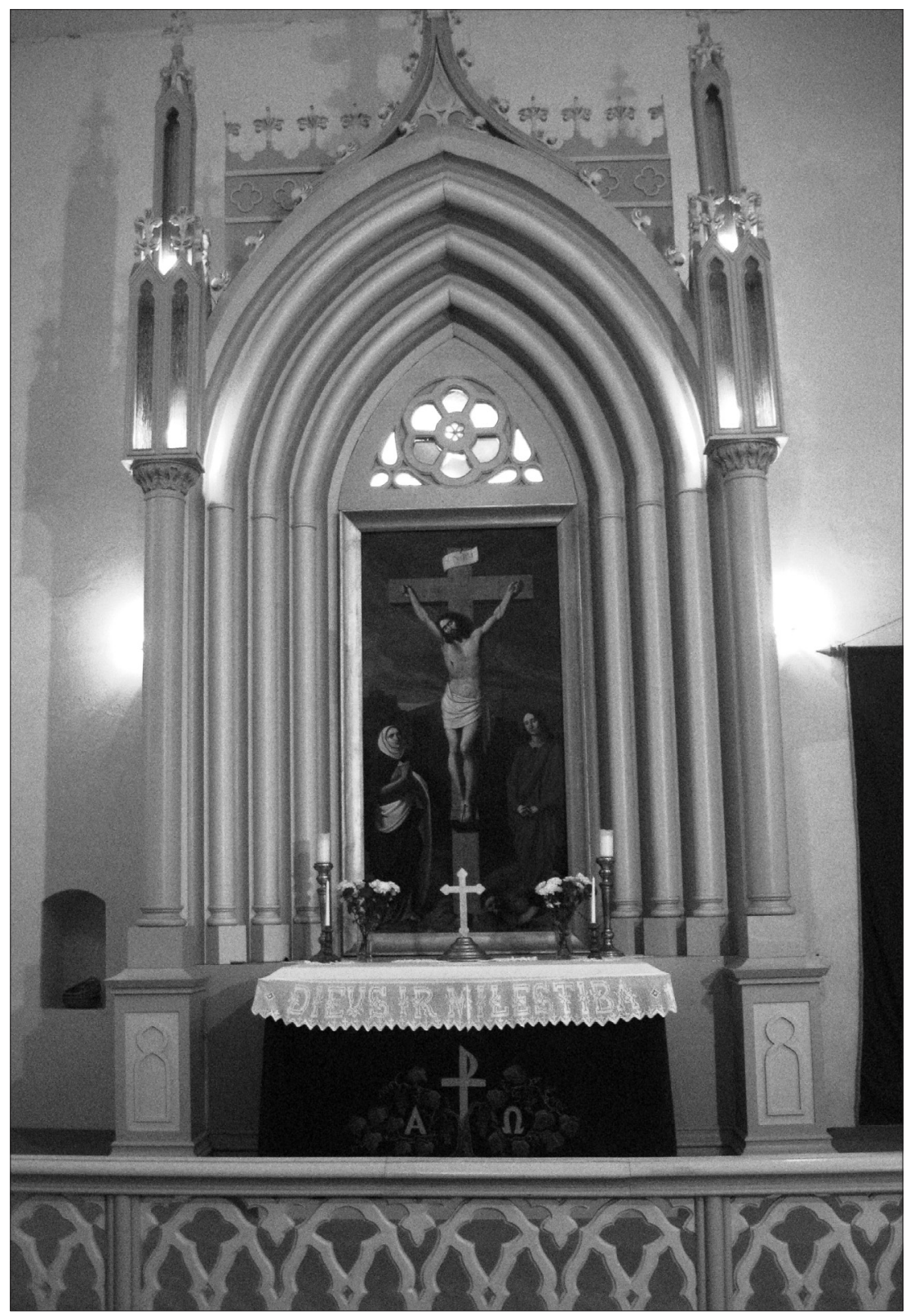

Sv. Bērtula baznīcas altāris ar Bergmaņu laika altārgleznu "Jēzus pie krusta", 1837. gads 
Riharda dēli, kas ietverti 7. paaudzē, ir pasaules slavu guvušais Ernsts (1836-1907) un viņa jaunākie brāḷi - skolotājs Gustavs (1840-1903) Kijevā, lauksaimnieks Frīdrihs (1843-1924) Igaunijā, matemātiķis un meteorologs Reinholds (1850-1913) Pēterburgā un pats jaunākais - mācītājs Eduards (1852-1900) Rūjienā, par kuru - daži vārdi vairāk.

Eduards bija pēdējais Bergmaņu dzimtas mācītājs Rūjienā, kur strādāja no 1878. gada. Viņš interesējās par vēsturi, savāca un apkopoja dzimtas arhīvu, kā arī 1886. gadā publicēja tās ǵenealoǵiju. Liktenis Eduardam nebija labvēlīgs, un 1889. gadā kādu nakti viņš pēkšņi pameta Rūjienu, domājams, kā konsekvents rusifikācijas pretinieks baidoties no vajāšanas. Būdams neprecējies, Eduards devās misionāra gaitās uz Kaukāzu, kur tika nogalināts kādā sadursmē.

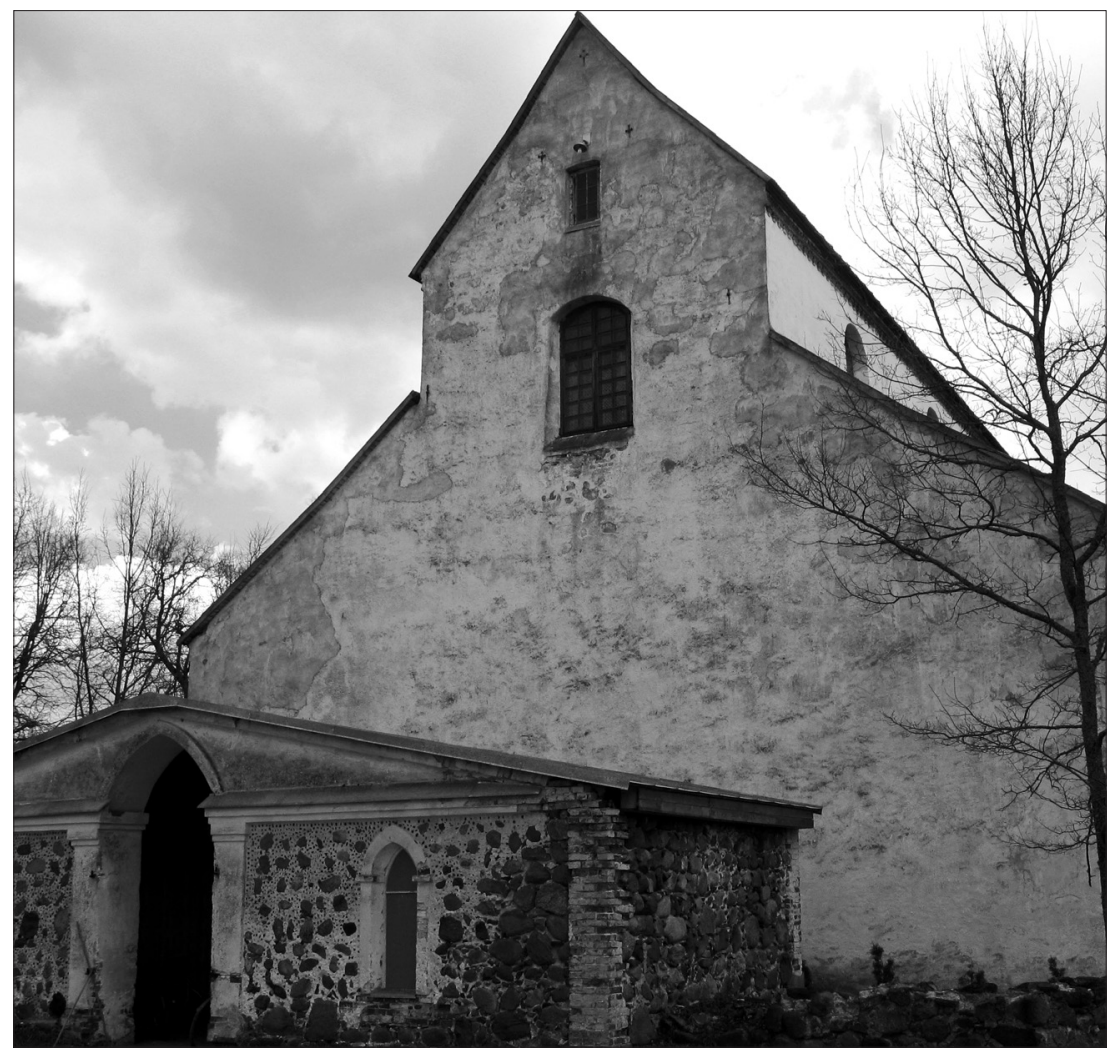

Sv. Bērtuḷa baznīca Rūjienā, 2011. gads 
Rūjienā, kur Bergmaṇi bijuši mācītāji četrās paaudzēs 104 gadus pēc kārtas, no 1785. līdz 1889. gadam (Gustavs, Benjamins, Rihards un Eduards), spilgtāko liecību par viņiem glabā Sv. Bērtuḷa baznīca. Tās celtniecības sākums tiek datēts ar 13. gs., un tā laikmetu vētrās daudz cietusi, pēdējo reizi - 1974. gada ugunsgrēkā, taču allaž atjaunota. Mūsu dienās kopā ar mūriem lieciniece no Bergmaņu laika ir altārglezna "Jēzus pie krusta", ko 1837. gadā Tērbatā darinājis gleznotājs Ludvigs Maidelis (1795-1845). Savukārt Rūjienas pastorāts turpat blakus, kur mituši Bergmaņi, nopostīts karadarbības laikā 1944. gadā, un tagad redzamas vien drupas. No saimniecības ēkām saglabājies stallis, kurā 1992. gadā ierīkota Rūjienas izstāžu zāle. Mācītāju atdusas vietas Ternejas kapos tika nopostītas 1952. gadā, tagad to vietā kuplo parks, kurā 1989. gadā nolikta akmens piemiņas zīme Gustavam Bergmanim.

Ar Ernsta fon Bergmaņa bērnību varētu būt saistīta Rūjienas aptieka, kas dibināta 1841. gadā, bet pirmais aptiekārs bijis Kārlis Georgs Tītjens (1815-1908), turklāt aptieka namā Rīgas ielā 3 atrodas līdz mūsu dienām.

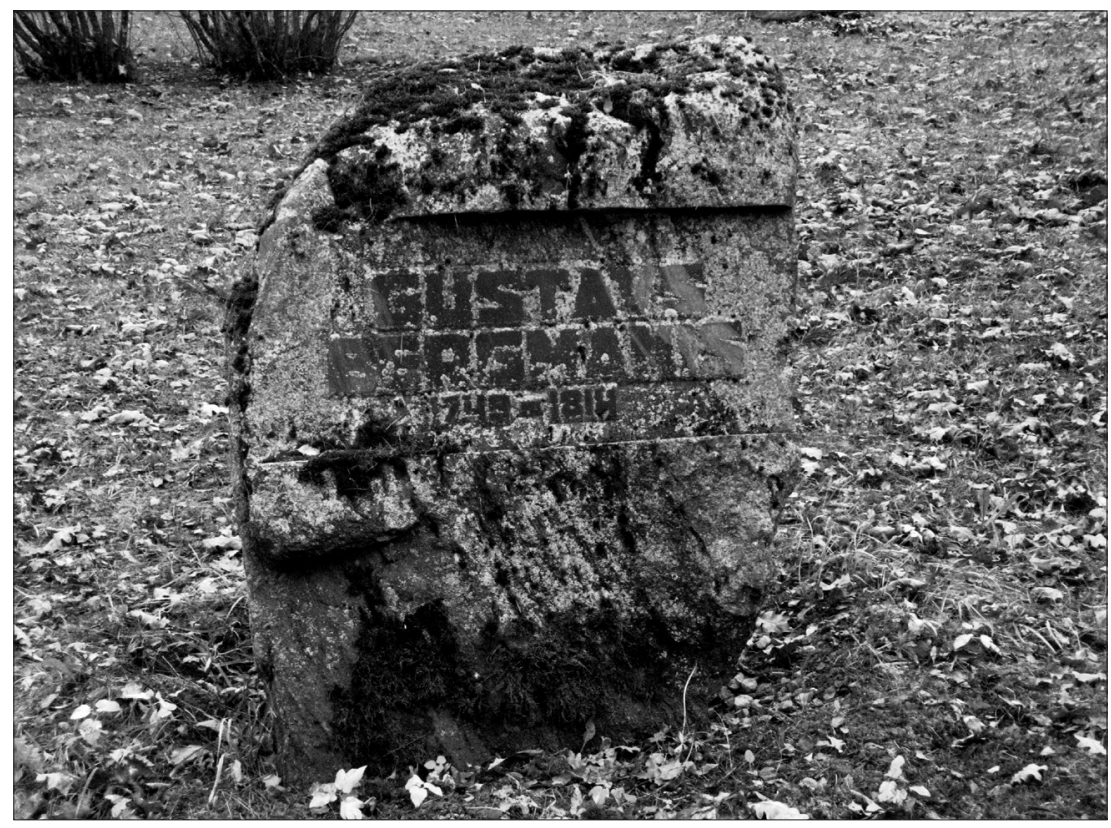

Gustava Bergmaņa piemiņas akmens Ternejas parkā Rūjienā, 2011. gads 


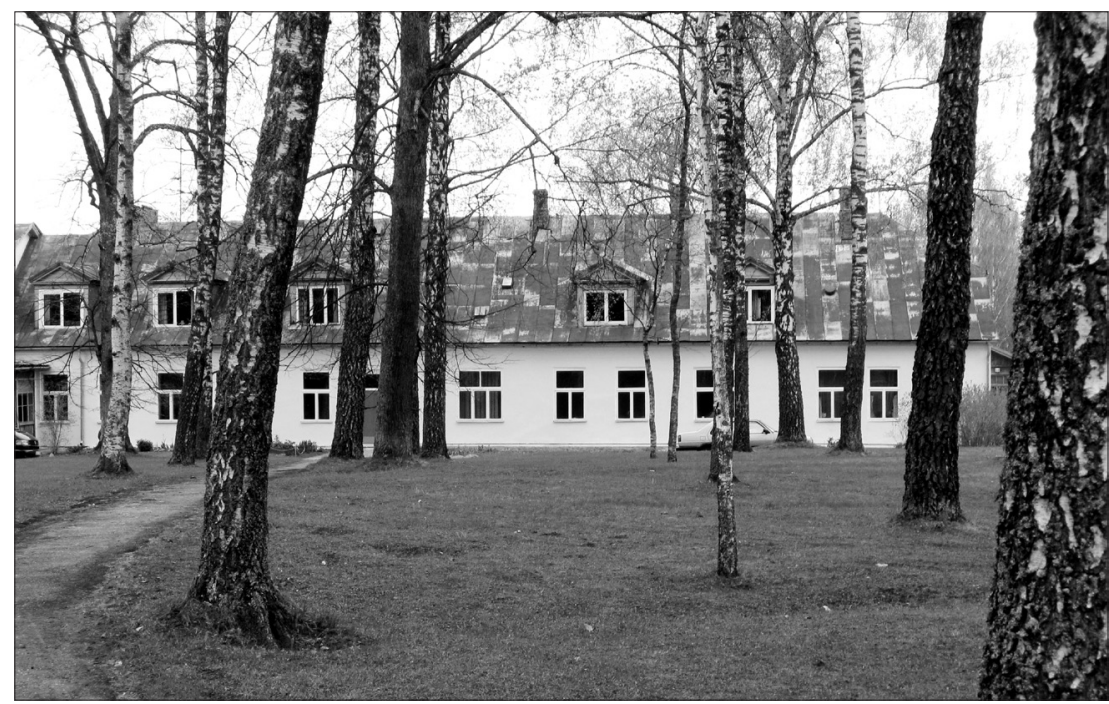

Bērzaines ǵimnāzijas vecā ēka Cēsīs, kas glabā Ernsta fon Bergmaṇa soḷus, 2011. gads

Pēc bērnības un mājmācības Rūjienā ar nelieliem pārtraukumiem, kad kopā ar vecākiem viņš ciemojies pie radiem Rīgā un Ērgḷos, nākamais Ernsta fon Bergmaņa dzīves posms no 1851. līdz 1854. gadam norisa Cēsīs, kur viñš mācījās 1825. gadā dibinātajā Bērzaines (Birkenruh), respektīivi, vēlāk ķeizara Aleksandra II, ǵimnāzijāân ${ }^{11}$ Tās galvenais korpuss, kas celts 1882. gadā pēc M. Kampes projekta (vēlāk tur mājojis Cēsu skolotāju institūts, ${ }^{12}$ bet tagad - sanatorija Meža skola), ar E. fon Bergmani tieši saistīts nav.

11 Bērzaines ğimnāzijā mācījušies daudzi sabiedrībā pazīstami ḷaudis: anatoms profesors Hermanis Adolfi (1863-1919), ārsts un filantrops Georgs Apinis (1859-1920), vēsturnieks profesors Frīdrihs Bīnemanis (1838-1903), ķirurgs profesors Jānis Dzirne (1861-1931?), zoologs profesors Gustavs Flors (1829-1883), ǵeologs profesors Konstantins Grevinks (1819-1888), paleontologs Gotfrīds Išreits (1868-1941), komponists Alfrēds Kalniņš (1879-1951), matemātiķis profesors Gustavs Kizerickis (1830-1896), RPI direktors Voldemārs Knīrims (1849-1935), mikrobiologs un epizootologs profesors Jānis Lūsis (1871-1922), ginekologs profesors Ernests Putniņš (1867-1962), agroķīmiķis Georgs Tomss (1843-1902) un daudzi citi. Sk. arī: Kröger C. Birkenruher-Album. - SPb., 1910. - 688 S.

12 Anspaks A. Cēsu skolotāju institūts. - Cēsis, 1995. - 147 lpp. 
Toties ir agrākā muižas un skolas ēka turpat blakus, tagad - saimniecības ēka (4. korpuss), ko iezīmē vējrādis ar gadskaitli "1813" un kas patiešām glabā Ernsta soḷu dunu.

Cēsīs ir saglabājušās daudzas ēkas, kas ir Ernsta fon Bergmaņa laika liecinieces, citu starpā - 1767. gadā celtais rātsnams Rīgas ielā 7, kurā kopš 1913. gada atrodas Vecpilsētas aptieka.

Turpmāk, no 1854. gada, E. fon Bergmanis studēja Tērbatā un pakāpeniski ieinteresējās par ķirurǵiju. Studiju starplaikos kopā ar biedriem viņš kājām apcelıja Vidzemes skaistākās vietas, piemēram, Koknesi un Staburagu. Ieguvis medicīnas doktora grādu 1860. gadā un turpmāk veidojot akadēmisko karjeru (būdams asistents, docents, profesors) - līdz pat 1878. gadam, kad, neguvis izaugsmes perspektīvu Krievijā, viņš pārcēlās uz Vāciju, E. fon Bergmanis brīvlaiku bieži pavadīja Rūjienā, kur labprāt ārstēja vietējos iedzīvotājus un labi sapratās ar viṇiem.

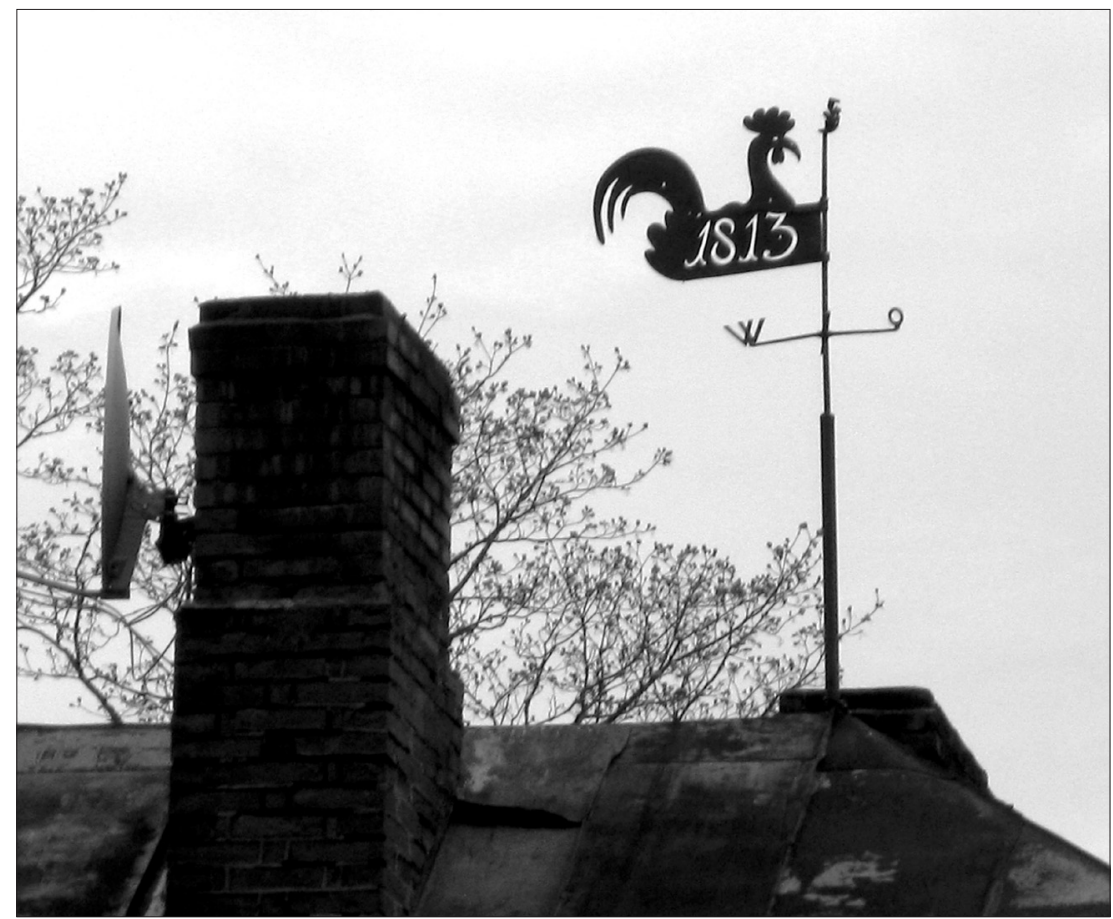

Vējrādis uz Bērzaines ǵimnāzijas vecās ēkas jumta, 2011. gads 
Starp E. fon Bergmaņa audzēkṇiem Tērbatā bija pirmais akadēmiski izglītotais latviešu ķirurgs Jūlijs Kalniņš (1848-1877) no Trikātas, kas profesora vadībā 1876. gadā aizstāvēja doktora disertāciju "Sēklinieku dermatoīdo cistu kazuistika un diagnostika". ${ }^{13}$

Diemžēl jaunā censoņa mūžs noslēdzās pāragri pašā spēju plaukumā; bērēs Tērbatas Jāṇa kapsētā E. fon Bergmanis teica izjustu atvadu runu..$^{14}$

Šajā laikā, konkrēti 1877. gadā, latviešu valodā tika pārtulkoti un periodikā publicēti divi E. fon Bergmaņa apraksti no Krievijas un Turcijas kara lauka. ${ }^{15}$

Darbojoties Vācijā (Vircburgā un no 1882. gada Berlīnē), E. fon Bergmanis saikni ar dzimto pusi nezaudēja un ik pa laikam šeit ieradās. Nozīmīgāka bija viesošanās Rūjienā 1885. gadā, kad 21. un 22. jūlijā draudzē un baznīcā tika svinēta mācîtāju Bergmaņu darbības simtgade. Laikrakstā "Baltijas Vēstnesis", piemēram, ziņots, ka "tagadējais mācītājs ir ceturtais auguma, kura brālis, slavenais medicīnas profesors, agrāki Tērbatas, tagad Berlīnes universitātē, arī būšot uz svētkiem. Arī šis vīrs, caur savu labprātīgu palīdzību ārstības ziņā, pie daudziem Rujenes draudzes locekļiem stāv pateicīgā piemiņā." ${ }^{16}$ Ernsts Rūjienā ieradās ar dzīvesbiedri Paulīni un bērniem Bertu, Alisi un Gustavu, lai kopā ar saviem četriem brālsiem, viņu ğimenēm, citiem radiniekiem, draudzes locekḷiem un viesiem piedalītos svinībās, kas plaši aprakstītas presē un viņa brāļa Eduarda īpaši sacerētā brošūrā. Kapsētā nolikts piemiņas akmens Bergmaņu senčiem ar dievbijīgu tekstu, ugunsdzēesēji rīkojuši lāpu gājienu, banketā teiktas runas (saglabājies arī Ernsta runas teksts), ${ }^{17}$ skandināti apsveikuma dzejoḷi, arī latviešu valodā, piemēram:

13 Kalning J. Zur Casuistik und Kenntniss der Dermoidcysten des Hodens. - Dorpat, 1876. - $39 \mathrm{~S}$.

14 Jūsmiņš [Lautenbahs J.] Uz pēdīgā ceḷa līdz pēdīgai vietiņai šinī pasaulē // Baltijas Vēstnesis, 1877. g. 4. maijs; Vīksna A. Pirmais latviešu ķirurgs Jūlijs Kalniņš // Latvijas Ārsts, 1998; 2: 113.-115. lpp.

15 [Bergmanis E.] Iz kopēju dzīves pie karā ievainotiem // Latviešu Avīze, 1877. g. 20., 27. jūl.; [Bergmanis E.] Par dzīvi Bulgārijā // Latviešu Avīze, 1877. g. 26. okt.

16 Rujeniets L. Rujenē // Baltijas Vēstnesis, 1885. g. 16. jūl.

17 Bergmann E. Das Säcularfest der Familie Bergmann. - S. 3, 4, 32, 47-50. 
“Tev, mīḷais gans, mēs vēlam

To Dieva svētīšan'

Pie miesas, kā pie dvēs'les

Un vis caur dzīvošan'!'18

Vai arī kāds cits, mazāk gluds, dzejojums:

"Tas vārds fon Bergmann tiešām mị̄̄̌š un cieṇā

Ikkatram, kas vien dzīvo Rūjenē.”'19

Šie svētki guvuši atspoguḷojumu arī latviešu presēe. ${ }^{20}$

Par to, ka E. fon Bergmanis labi runājis latviski, saglabājusies savdabīga liecība:

"Kāds Vidzemes muižnieks aizsūtījis pie Bergmaņa uz Berlīni savu zemnieku. Tas, gulēdams uz operācijas galda, sācis skaitīt Tēvreizi. Pienācis Bergmanis un sācis skaitīt līdz. Pārsteigtais zemnieks pēc "Āmen" vaicājis, vai tad augstais kungs tik tiešām protot vienkāršu zemnieka valodu. Bergmanis atbildējis, ka tā esot viņa bērnu dienu valoda." 21

Liekas, ka pēdējoreiz Latvijā E. fon Bergmanis pabijis 1898. gadā pa cel̦am uz Pēterburgu, lai saņemtu Kara medicīnas akadēmijas, kas viṇu pirms 20 gadiem bija atraidījusi, goda locekḷa diplomu. Viṇu pavadījis dēls Gustavs, medicīnas students, kas senču dzimteni uzlūkojis par vilku apsēstu zemi.

Rīgas Praktizējošo ārstu biedrība, kas bija sekmējusi strauju aseptikas ieviešanu Latvijā, 1906. gadā, atzīmējot E. fon Bergmaņa septiņdesmito dzimšanas dienu, viņam pasniedza goda adresi. ${ }^{22}$ Latviešu presē tika publicēts jubilejas apraksts. ${ }^{23}$

\footnotetext{
18 Bergmann E. Das Säcularfest der Familie Bergmann. - S. 3, 4, 32, 47-50.

19 Turpat.

20 Iz Rujenes // Baltijas Vēstnesis, 1885. g. 29. jūl.; No Rujenes // Latviešu Avīze, 1885. g. 31. jūl.

21 Pavasars R. Ievērojams vidzemnieks // LĀZA Apkārtraksts, 1980; 119: 28. 1pp.

22 Goda adrese - apsveikuma raksts glītā noformējumā.

23 Ievērojama jubileja // Latvija, 1906. g. 4. dec.
} 
Rīgā E. fon Bergmanim tuvāks cilvēks bija otrās pakāpes brālēns Ādolfs fon Bergmanis, pie kura Ernsts viesojies vismaz divas reizes viña mājā Skolas ielā 5 (tās vietā 1937. gadā pēc A. Klinklāva projekta uzcelta pašvaldības darbinieku slimokases ambulance jeb tagad - medicīnas sabiedrība “ARS"), pie reizes apmeklējot Ādolfa darbavietu 1. slimnīcā. Ādolfs uzaicinājis Ernstu uz savas meitas Elizabetes kāzām Rīgā 1907. gada aprīlī un saņēmis piekrītošu atbildi, taču Ernsts nomiris 25. martā, un Ādolfs devies uz Berlīni ar dzimtenes skuju vainagu. ${ }^{24}$

Par Ādolfu fon Bergmani daži vārdi vairāk, jo sava slavenā radinieka vistiešākā ietekmē viņš pacēla Rīgas ķirurǵiju līdz Eiropas līmenim. Pēc medicīnas doktora grāda iegūšanas Tērbatā 1881. gadā un papildstudijām Vakareiropā viņš no 1883. gada bija Rīgas pilsētas 1. slimnīcas 2. ķirurǵijas nodaḷas un no 1890. līdz 1919. gadam - 1. ķirurǵijas nodaļas virsārsts, savā klīnikā ieviesa aseptiku, dobumoperācijas, moderno ķirurǵiju, kā ar̄i izveidoja Rīgas ķirurgu skolu, ${ }^{25}$ bet viņa 30 gadu darba jubileja 1913. gadā tika atzīmēta ar īpašu, apjomīgu vācu ķirurgu žurnāla izdevumu. ${ }^{26} \bar{A}$. fon Bergmanis bija arī ar iniciatīivu apveltīts, krietns celtnieks: nodibināja Rīgas leprozoriju (tagad - Latvijas Infektologiijas centrs) 1891. gadā, Rīgas 1. ambulanci (poliklīniku) arī 1891. gadā, Rīgas ātrās palīdzības staciju 1904. gadā, sekmēja Rīgas 1. slimnīcas izbūvi un 2. (tagad - Paula Stradiṇa Klīniskās universitātes) slimnīcas celtniecību 1910. gadā. ${ }^{27}$ Aizejot pensijā, pilsētas dome 1919. gadā ievēlēja viṇu par Rīgas pilsētas goda pilsoni. ${ }^{28}$

Cits pagodinājums sekoja septiņus gadus pēc $\bar{A}$. fon Bergmaņa nāves - 1929. gadā dome viņa vārdā nosauca kādu no Mežaparka jaunajām ielām. Lai nosaukums nebūtu pārāk garš, domnieki nolēma, ka pietiktu tikai ar uzvārdu, proti - Bergmaņa iela, ${ }^{29}$ jo visi taču viņu pazīstot, kas savukārt vēlāk izraisīja nepatīkamu pārpratumu.

${ }^{24}$ LVVA, 3981. f., 1. apr., 72. 1., 20. 1p.

25 Vīksna A. Ādolfs fon Bergmanis un Rīgas ķirurgíija // Latvijas Ārsts, 1994; 8: 678.-680. lpp.

26 Deutsche Zeitschrift für Chirurgie // 1913, Bd. 124. - 429 S.

27 Vīksna A. Ādolfs fon Bergmanis un Rīgas iedzīvotāju veselības aprūpe // Ķirurgíijas divi gadsimti. Rīgas 1. slimnīca. - Rīga, 2002. - 43.-48. lpp.

28 LVVA, 2927. f., 1. apr., 209. 1.

29 Rīgas pilsētas domes 1929. gada protokoli. - Rīga, 1929. - 607., 608., 634. lpp. 


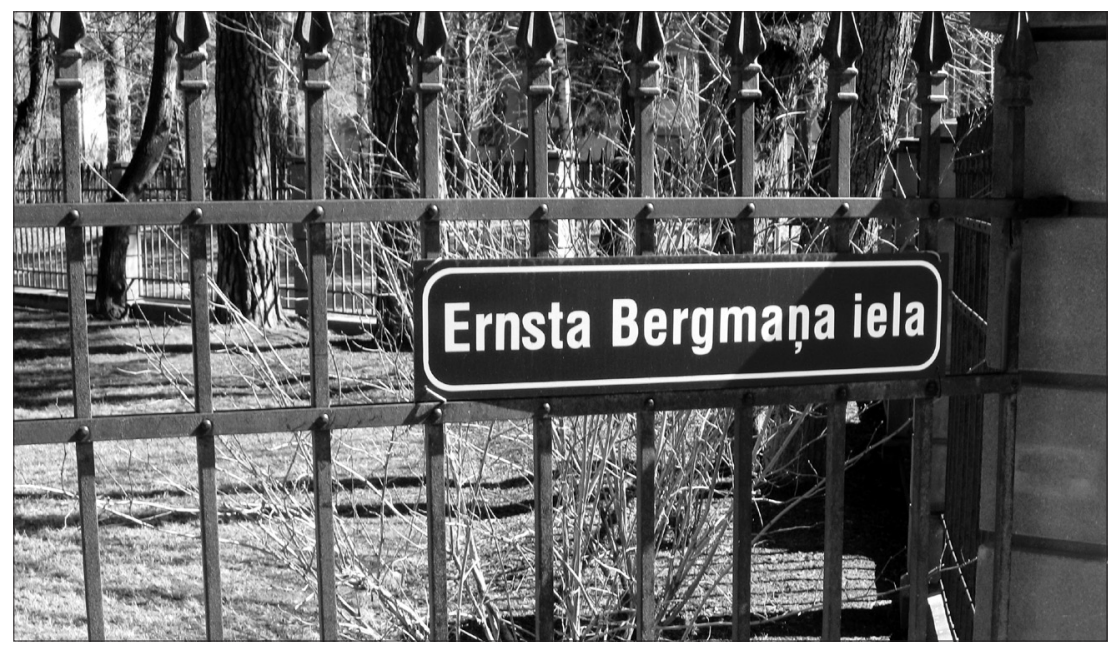

Ernsta Bergmaņa ielas plāksne Rīgā, Mežaparkā, 2011. gada foto

Precizējot ielu nosaukumus 1987. gadā, kad $\bar{A}$. fon Bergmanis jau bija pamatīgi aizmirsts, radās šaubas, vai tikai nav godināts viṇa vecvectēvs Gustavs Bergmanis, jo Mežaparkā bija vairākas garīgo darbinieku (Glika, Fīrekera, Stendera, Vatsona) vārdā nosauktas ielas. Pēc viedokḷu apmaiņas $230 \mathrm{~m}$ garās ieliņas ar četriem gruntsgabaliem vārdu tika nolemts precizēt un turpmāk dēvēt slavenā ķirurga vārdā - par Ernsta Bergmaņa ielu.

Lai atjaunotu sākotnējo nosaukumu, 2000. gadā tika sagatavots vēsturisks pamatojums, taču dome, nogurusi ielu nosaukumu nemitīgā maiņā, lēmumprojektu noraidīja - neesot vērts atgriezties pie nosaukuma Bergmaņa iela, jo tik un tā gan Ādolfs, gan Ernsts esot cienījami mediķi. ${ }^{30}$

Taču jāpiebilst, ka Ernsta fon Bergmaņa iela Rīgā ir pastāvējusi jau agrāk, jo tā no 1942. līdz 1944. gadam saukta Antonijas iela. ${ }^{31}$ Antonijas (padomju laikā - Leona Paegles) ielā 1 atrodas Paula Stradiṇa Medicīnas vēstures muzejs, kura dārzā 1975. gadā novietots tēlnieka Ojāra Breǵa akmen̄i kaltais Ernsta fon Bergmaña skulptūrportrets (diplomdarbs, beidzot Latvijas PSR Valsts Mākslas akadēmiju).

30 Nepārdēvēs Ernsta Bergmaņa ielu // Rīgas Balss, 2000. g. 25. okt.

${ }^{31}$ Rīgas ielu, laukumu, parku un tiltu nosaukumu rādītājs (no 18. gs. līdz mūsdienām). - Rīga, 2001. - 46. lpp. 


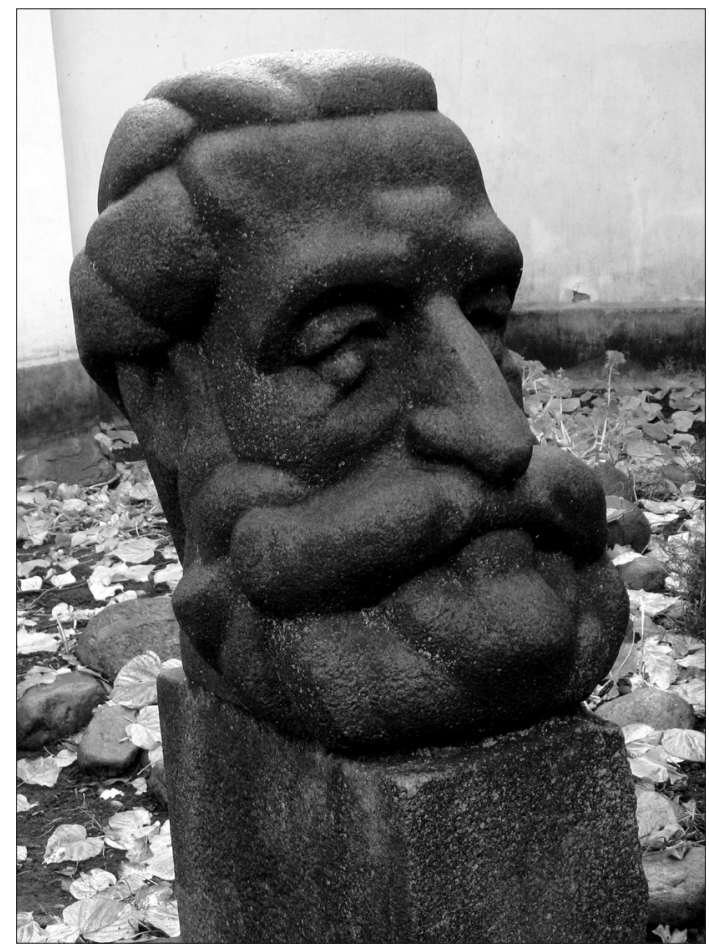

Ernsta fon Bergmaņa skulptūrportrets

Paula Stradinna Medicīnas vēstures muzeja dārzā.

Tēlnieks Ojārs Breǵis, 1975. gads

Latvijas Medicīnas vēsturnieku biedrība 1986. gada 25. decembrī muzejā rīkoja E. fon Bergmaņa 150 gadu piemiņas sēdi. Tajā tēlnieka Jāṇa Strupuḷa veidotā Ernsta fon Bergmaņa medaļa tika pasniegta četriem ķirurgiem: profesoram Viktoram Kalnbērzam, profesoram Vilim Purmalim (1927-1989), Jānim Strodam un profesoram Vladimiram Utkinam (1932-1994), kas pats kādreiz rakstījis par E. fon Bergmani. ${ }^{32}$ Referātus nolasīja profesors Haralds Voskis (1928-2011) “E. Bergmaņa dz̄ive un zinātniskā darbība" un Arnis Vīksna "E. Bergmaņa piemiņas vietas Latvijā̄". Notika jubilejas izstādes apskate, bet nobeigumā dalībnieki

32 Уткин В. В. Эрнст Бергман // Из истории медицины. - Т. 2. - Рига, 1959. - C. 291-293. 
tika iesaistīti diskusijā, vai E. fon Bergmanis traktējams kā vācu vai kā krievu zinātnieks (ar noslieci uz pēdējo). Jubileja guva atspogulojumu Latvijas presē. ${ }^{33}$

Jau pēc Latvijas valstiskās neatkarības atgūšanas Rūjienā pie agrākās mācītājmuižas 1992. gada 5. jūnijā tika atklāts piemineklis Ernstam fon Bergmanim un četru paaudžu Rūjienas mācītājiem Bergmaņiem: uz četrstūrveida pamatnes - raupjš laukakmens, kurā iedziḷināts pret debesīm vērsts zeltīts krusts (tēlnieks Andris Vārpa, akmeņkalis Aivars Muzikants). Rūjienas izpildkomitejas priekšsēdētāja Alma Zālīte atklāšanas runu noslēdza vārdiem: "Saulei pretī krusts metīs starus pāri pasaulei”, Bonnas universitātes klīniskās farmakologijas profesors Klauss fon Bergmanis pateicās par sava vecvectēva piemiņas saglabāšanu ("Senču ēna ir smaga...”), vēl runāja Vācu ķirurgu biedrības ǵenerālsekretārs profesors Edgars Ungeheiers no Berlīnes un Veselības departamenta direktora vietnieks Juris Lange, bet pieminekli iesvētīja palīgmācītājs Ivo Grantiņš ("Lai krusts nebūtu dekorācija, bet liecība uzvarai dzīvības un nāves cīṇā"). Vienīgajā pastorāta ēkā, kas saglabājusies - stallī - tika atklāta Rūjienas izstāžu zāle, bet pēcpusdienā pilsētas kultūras namā notika konference, ko rīkoja Latvijas Ķirurgu zinātniskā biedrība, Latvijas Ķirurgu asociācija, Baltijas Bērnu ķirurgu asociācija un Latvijas Medicīnas vēsturnieku apvienība un kurā pēc muzikāla ievada referēja profesors V. Utkins, profesors H. Voskis, A. Vīksna, profesors E. Ungeheiers un profesors Lembits Rostars no Tartu. ${ }^{34}$

Divus gadus vēlāk, 1994. gadā no 12. līdz 14. septembrim, Rīgā, Paula Stradiņa Medicīnas vēstures muzejā notika starptautisks simpozijs "Ernsts fon Bergmanis un viņa laikmets medicīnā”, kurā zinātnieki no Latvijas, Vācijas, Lietuvas, Norvēgijas un Austrālijas nolasīja 16 referātus. ${ }^{35}$

33 Goba V. Piešksirtas E. Bergmaņa pieminnas medal̦as // Cīṇa, 1986. g. 26. dec.; Arāja M. Atcere // Liesma, 1987. g. 6. janv.; Vīksna A. Ernsta Bergmaņa piemiñas medaḷa // Veselība, 1987; 3: 5. lpp.; Zanders V. Darbīgas dzimtas atvase // Dzimtenes Balss, 1987. g. 1. janv.

${ }_{34}$ Vīksna A. Ernsts fon Bergmanis Latvijā // Latvijas Ārsts, 1992; 6: 643.-646. lpp.

35 Vīksna A. Latvijas Medicīnas vēsturnieku apvienības darbības pārskats no 1993. gada maija līdz 1997. gada 1. janvārim // Acta medico-historica Rigensia. Vol. III (XXII). - Rīga, 1997. - 367.-384. lpp.; Salaks J. Konference Paula Stradiṇa Medicīnas vēstures muzejā // Muzeju Vēstnesis, 1994; 6. 
Vēlāk tika publicēti akadēmiķa Jāṇa Stradiṇa teiktie ievadvārdi ${ }^{36}$ un Venta Miltiņa referāts, ${ }^{37}$ kā arī trīs vācu zinātnieku referāti, kas nebija saistīti ar Latviju.

Gan 1992., gan 1994. gada sarīkojumos piedalījās vairāki Ernsta fon Bergmaņa tiešie pēcteči no Vācijas. Viņa dēls Gustavs fon Bergmanis (1878-1955), kas ir ievērojamākais 8. paaudzes pārstāvis, bija klīnicists, funkcionālās patoloğijas profesors, Vācu dabaszinātnieku un ārstu biedrības prezidents. Devītajā paaudzē savukārt ievērojamāks ir Gustava dēls Frīdrihs fon Bergmanis (1907-1982), Rietumberlīnes Brīvās universitātes līdzdibinātājs, bet 10. paaudzē - jau minētais Klauss fon Bergmanis (1940), kas kopā ar māsu Helgu Rēku (1936) bija Rūjienā; viņiem 11. paaudzē seko Klausa bērni Jens (1973) un Kirstene (1976), bet daudzi citi slavenās dzimtas pārstāvji šeit paliek nepieminēti.

Gatavojoties E. fon Bergmaņa 175. dzimšanas dienai, tika rūpīgi pārdomāta viņa piemiņas tālāka iemūžināšana Rūjienā, piel̦aujot, ka kāda no pilsētas ielām varētu saukties viņa, bet vēl labāk - Bergmaņu vārdā. Par piemērotāku tika atzīta Mācītājmuižas iela ar trim mājām, kas visas izrādījās administratīvi piederīgas Rīgas ielai, proti, agrākais stallis (tagad - izstāžu zāle), kučiera un kalpu māja lokā ap mācītājmuižas drupām. Ernsta laika liecinieks noteikti ir stallis, kučiera māja - krietni jaunāka, bet kalpu māja tik ļoti pārbūvēta, ka vecums nenosakāms.

Rūpīgāk iepazīstoties ar pastorāta teritoriju, uzman̄̄bu piesaistīja akmens ar riņķa krustu un vēl kāds piemiņas akmens turpat blakus zem pāraugušu koku zariem agrākā parka vietā. Arheologs Juris Urtāns pierakstījis nostāstu, ka senos laikos kāds zviedrs uzbrucis baznīcai, ticis ievainots un izdziedinājies ar tuvējā avota ūdeni, kam par piemiṇu nolikts krustakmens. ${ }^{38}$ Tik tiešām, turpat netālu ir senču svētvieta jeb svētavots, kas tagad pārveidots akā, bet tam iepretī uzcelta Sv. Bērtuḷa baznīca (pēc analoǵijas - bruņinieku mūra pilis celtas iepretī senču

36 Stradiņš J. Zur Eröffnung des Internationalen Symposiums "Ernst von Bergmann und die Medizin seiner Zeit" // Acta medico-historica Rigensia. Vol. III (XXII). - Rīga, 1997. - 173.-177. lpp.

37 Miltiņš V. Ernsta Bergmaņa pētījumi par sifilisu un lepru Vidzemes guberņā // Acta medico-historica Rigensia. - Vol. III (XXII). - Rīga, 1997. - 211.-215. lpp. 38 Urtāns J. Pēdakmeņi, robežakmeņi, muldakmeņi. - Rīga, 1990. - 43., 44. lpp. 
pilskalniem). Novadpētnieks Laimonis Liepnieks savukārt pamanījis akmen̄̄ zem krusta iecirsto gadskaitli "1813”, ko skaidrojis kā mācītāja Gustava Bergmaņa veidotu piemiņas zìmi saviem dēliem - 1812. gada kara dalībniekiem. ${ }^{39}$

Bet gala slēdzienu savā riņķa krustiem veltītā monogrāfijā devis arheologs Andris Caune. Blakusakmen̄̄, kurā iekalts gadskaitlis "1875”, viņš samanījis suṇa vārdu Ipsi vai Lipsi (akmeni varētu būt licis Ernsta tēvs Rihards), tālab A. Caune secina, ka te atrodas Rūjienas mācītāju iemīḷoto suņu kapsēta. Akmens ar riņķa krustu gan sākotnēji varētu būt atradies pie netālās Sv. Bērtuḷa baznīcas viduslaiku kapsētā, ko senatnes cienītājs Gustavs licis pārvietot uz mācītājmuižas parku un iekalt tajā sava mīḷtōā suña miršanas gadu. ${ }^{40}$

Šī pagātnes palieka kopā ar jaunu nostāstu, ka stallī (izstāžu zālē) sācis spokoties kāds Ambrozijs, Bergmaņu sencis, diezgan nolaisto apkārtni dara interesantāku. Mācītājmuižas iela Rūjienā par Bergmaņu ielu gan netika pārdēvēta, un labi arī tā.
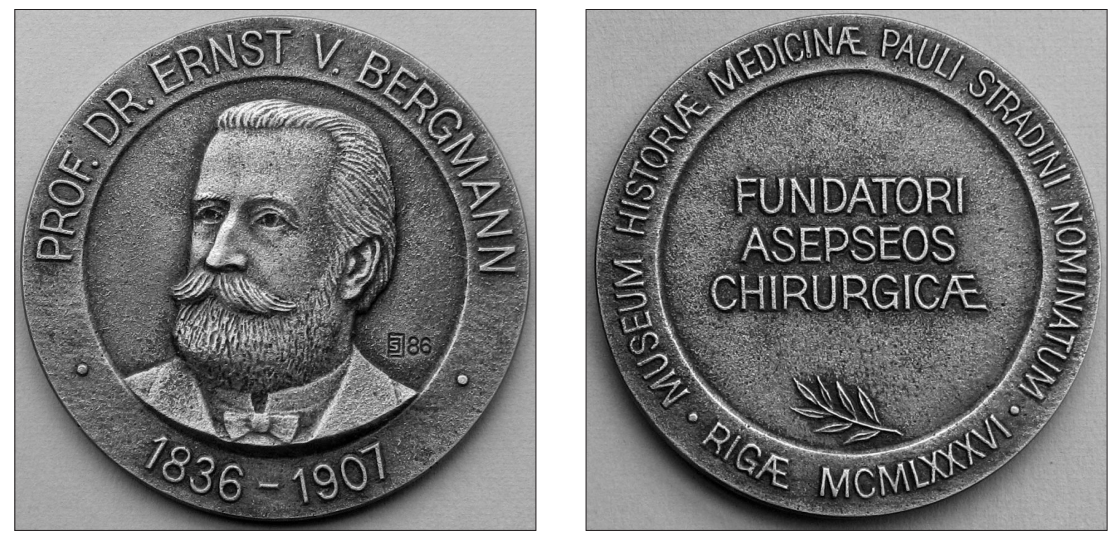

Ernsta fon Bergmaņa piemiņas medaļa: averss un reverss.

Tēlnieks Jānis Strupulis, 1986. gads

39 Liepnieks L. Dzelzs krusts mācītāja muižas dārzā // Liesma, 2001. g. 12. janv.

40 Caune A. Riņķa krusti Latvijā. - Rīga, 2008. - 130.-134. lpp. 


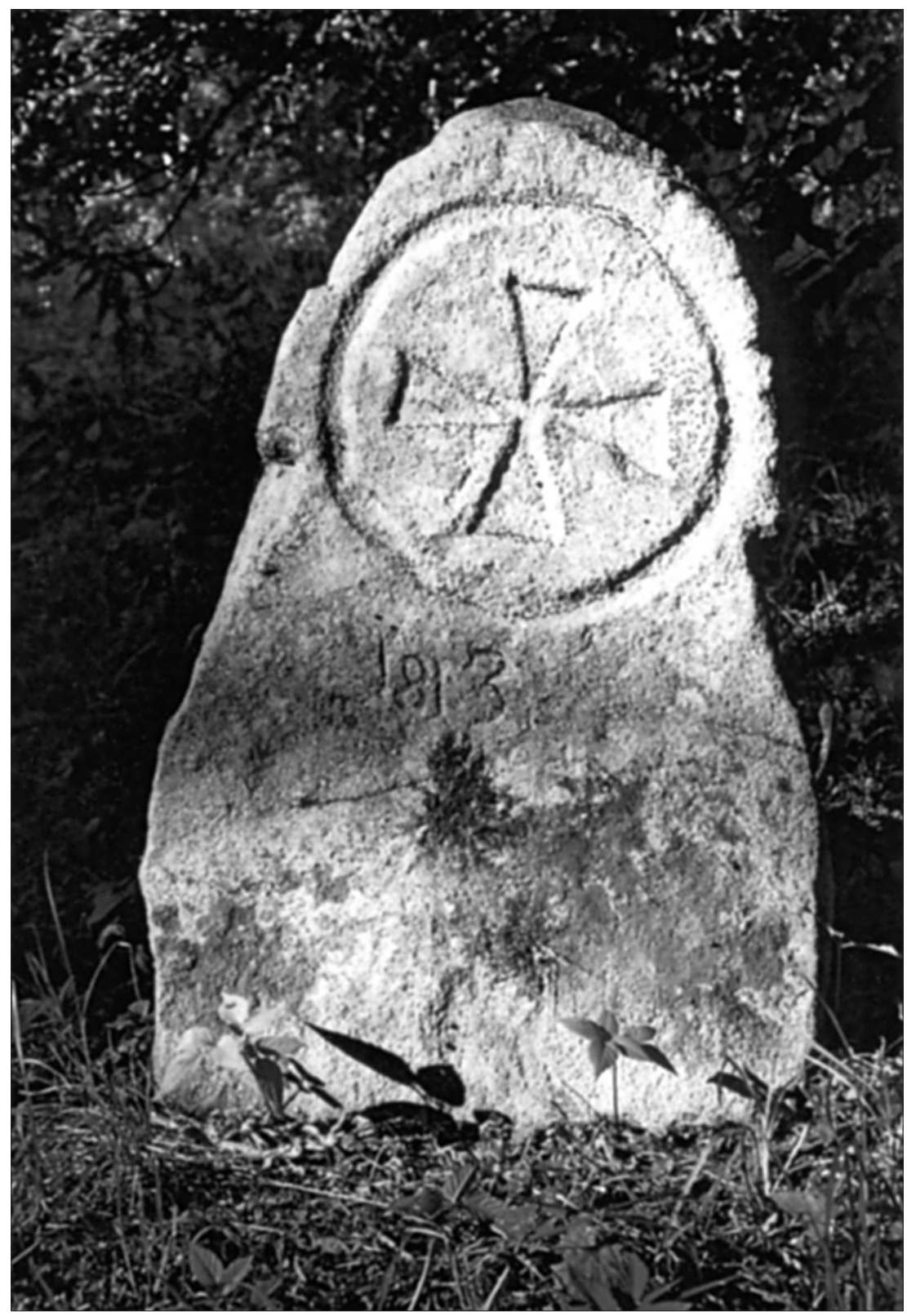

Rūjienas neregulārais akmens krusts ar iekaltu riņķa krusta veidojumu, 2006. gada foto 


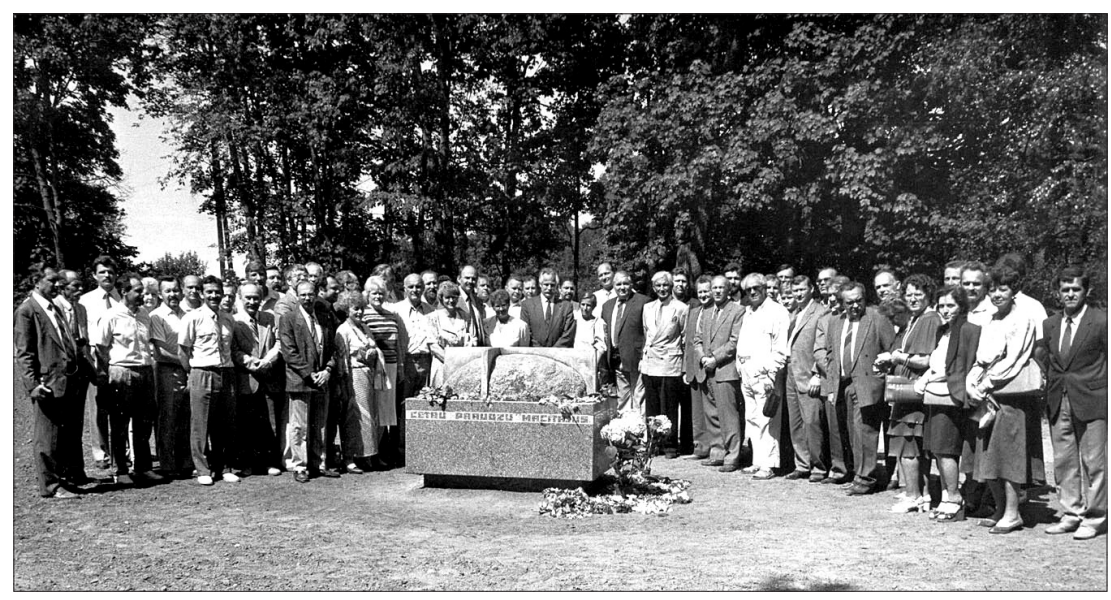

Latvijas ķirurgi pie Bergmaņu pieminekḷa Rūjienā atklāšanas dienā - 1992. gada 5. jūnijā

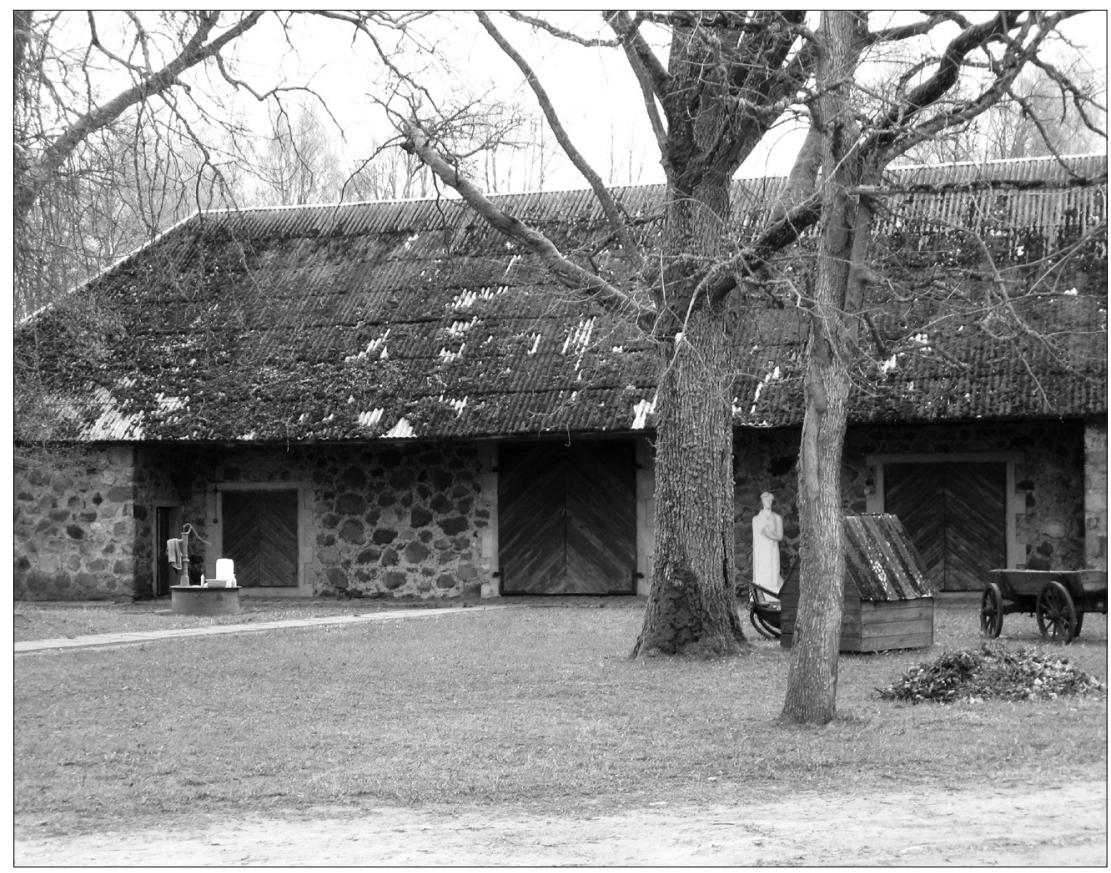

Rūjienas mācītājmuižas stallis, kopš 1992. gada - izstāžu zāle 
Palūkojoties latviešu valodā publicētajā literatūrā par Ernstu fon Bergmani, jāsecina, ka tā diezin ko plaša nav un atkārto vienus un tos pašus faktus. Pēc Otrā pasaules kara, kad jebkas vācisks tika uzlūkots ar aizdomām, pirmos divus rakstus publicēja tolaik jauni ķirurgi Vestards Sosārs (1929-2000) ${ }^{41}$ un Vitāls Oga (1929-1984). ${ }^{42}$ Vēlāk rakstījuši novadpētnieks Andrejs Kursītis (1919-1990), ${ }^{43}$ dzejnieks Valdis Rūja, ${ }^{44}$ kultūrvēsturnieks Ojārs Zanders, ${ }^{45}$ Rūjienas izstāžu zāles direktore Līga Siliņa ${ }^{46}$ un šo rindu autors. ${ }^{47}$ Galvenokārt izmantota rīdzinieka, žurnālista un vēsturnieka, Ernsta brālēna Ārenda Buholca (1857-1928) pirms gadsimta Leipcigā vācu valodā publicētā monogrāfija, kas turpmāk pieredzējusi daudzus atkārtotus izdevumus līdz pat mūsu dienām (piemēram, 2010. gadā N̦ujorkā). Arī latviešu lasītājam būtu lietderīgi iepazīties ar šo laika pārbaudi izturējušo darbu. ${ }^{48}$

Tas ir l̦oti apjomīgs, tālab tulkošana un izdošana būtu pagrūti īstenojama, un varbūt izlīdzēties ar īsinātu, mūsu lasītājam adaptētu izdevumu. Tas būtu vēl viens labs darbs Ernsta fon Bergmaņa piemiņas iemūžināšanā viņa dzimtenē.

Sosārs V. Ernsts Bergmans // Padomju Jaunatne, 1957. g. 17. apr.

42 Oga V. Ķirurgs, ar ko medicīna lepojas // Veselība, 1961; 12: 12.-13. lpp.

${ }^{43}$ Kursītis A. Rūjienas Bergmaņu dzimta // Liesma, 1987. g. 26. jūn.

${ }^{44}$ Rūja V. Zelta skalpelis (pēc vācu vēsturnieka A. Buholca u. c. materiāliem) // Elpa, 1994. g. 5. aug., 2. sept.

45 Zanders O. No slavenas Vidzemes mācītāju dzimtas // Latvijas Luterānis, 1999. g. 4. sept.

46 Siliņa L. Tā bija pirmā siltā pavasara diena // Liesma, 2007. g. 24. marts; t. p. // Brīvā Latvija, 2007. g. 31. marts; t. p. // Laiks, 2007. g. 31. marts.

47 Vīksna A. Ernsts Bergmanis Latvijā // Veselība, 1980; 3: 3. v.; Vīksna A. Pa ārstu takām. - Rīga, 1990. - 20.-21. lpp.; Vīksna A. Ernsts fon Bergmanis // Veselība, 1995; 8: 32. lpp.; Vīksna A. Ko godina Bergmaņa iela Rīgā? // Tava labākā grāmata par Latviju - 3. d. - Rīga, 1998. - 101., 102. lpp.

48 Buchholtz A. Ernst von Bergmann. Mit Bergmanns Kriegsbriefen von 1866, 1870/71 und 1877. - Leipzig, 1911. - 646 S. 


\section{Ernst von Bergmann and Latvia}

\section{Abstract}

A brief look at the relationship which the distinguished surgeon Ernst von Bergmann (1836-1907) had with Latvia, looking at places in Riga, Rujiena and Cesis which were linked to his life and also focusing on the preservation of his memory via various objects, events and publications.

The world-famous surgeon, founder of asepsis Ernst von Bergmann was born in Riga. He first studied in Terbata (Estonia), later continued his studies while also working as the lecturer in Germany - Würzburg and Berlin; this was also the time he visited his home-land on several occasions.

The article presents a brief look at the relationship which the distinguished surgeon Ernst von Bergmann (1836-1907) had with Latvia, referring to such places as Riga, Rüjiena and Cēsis which were linked to his life. The article also focuses on the preservation of his memory via various objects, events and publications.

Arnis Vīksna, Dr. med., profesors

Paula Stradiņa Medicīnas vēstures muzejs

arnis.viksna@mvm.lv 